University of Nebraska - Lincoln

DigitalCommons@University of Nebraska - Lincoln

Papers in Veterinary and Biomedical Science

Veterinary and Biomedical Sciences,

Department of

October 2000

\title{
Clinical, pathological and antigenic aspects of bovine viral diarrhea virus (BVDV) type 2 isolates identified in Brazil
}

\author{
E. F. Flores \\ Universidade Federal de Santa Maria, 97105-900 Santa Maria, RS, Brazil \\ L. H. G. V. Gil \\ Universidade Federal de Santa Maria, 97105-900 Santa Maria, RS, Brazil
}

S. A. Botton

Universidade Federal de Santa Maria, 97105-900 Santa Maria, RS, Brazil

R. Weiblen

Universidade Federal de Santa Maria, 97105-900 Santa Maria, RS, Brazil

J. F. Ridpath

Metabolic Diseases and Immunology Research Unit, NADC, ARS/USDA, Ames, IA

See next page for additional authors

Follow this and additional works at: https://digitalcommons.unl.edu/vetscipapers

Part of the Veterinary Medicine Commons

Flores, E. F.; Gil, L. H. G. V.; Botton, S. A.; Weiblen, R.; Ridpath, J. F.; Kreutz, L. C.; Pilati, C.; Driemeyer, D.; Moojen, V.; and Wendelstein, A. C., "Clinical, pathological and antigenic aspects of bovine viral diarrhea virus (BVDV) type 2 isolates identified in Brazil" (2000). Papers in Veterinary and Biomedical Science. 88. https://digitalcommons.unl.edu/vetscipapers/88

This Article is brought to you for free and open access by the Veterinary and Biomedical Sciences, Department of at DigitalCommons@University of Nebraska - Lincoln. It has been accepted for inclusion in Papers in Veterinary and Biomedical Science by an authorized administrator of DigitalCommons@University of Nebraska - Lincoln. 


\section{Authors}

E. F. Flores, L. H. G. V. Gil, S. A. Botton, R. Weiblen, J. F. Ridpath, L. C. Kreutz, C. Pilati, D. Driemeyer, V. Moojen, and A. C. Wendelstein

This article is available at DigitalCommons@University of Nebraska - Lincoln: https://digitalcommons.unl.edu/ 


\title{
Clinical, pathological and antigenic aspects of bovine viral diarrhea virus (BVDV) type 2 isolates identified in Brazil
}

\author{
E.F. Flores ${ }^{\mathrm{a}, *}$, L.H.G.V. Gil ${ }^{\mathrm{a}, \mathrm{b}}$, S.A. Botton ${ }^{\mathrm{a}}$, R. Weiblen ${ }^{\mathrm{a}}$, \\ J.F. Ridpath ${ }^{\mathrm{c}}$, L.C. Kreutz ${ }^{\mathrm{a}}$, C. Pilati ${ }^{\mathrm{d}}$, D. Driemeyer ${ }^{\mathrm{e}}$, \\ V. Moojen ${ }^{\mathrm{e}}$, A.C. Wendelstein ${ }^{\mathrm{e}}$ \\ ${ }^{a}$ Departamento de Medicina Veterinária Preventiva, e Departamento de Microbiologia e Parasitologia, \\ Universidade Federal de Santa Maria, 97105-900 Santa Maria, RS, Brazil \\ b236-VBS, Department of Veterinary and Biomedical Sciences, University of Nebraska at Lincoln, \\ Lincoln, NE 68583-0905, USA \\ ${ }^{\mathrm{c}}$ Metabolic Diseases and Immunology Research Unit, NADC, ARS/USDA, Ames, IA 50010, USA \\ ${ }^{\mathrm{d}}$ Centro Agroveterinário de Lages, Universidade de Santa Catarina (UDESC), Lages, SC, Brazil \\ ${ }^{\mathrm{e}}$ Faculdade de Veterinária, Universidade Federal do Rio Grande do Sul, UFRGS, Porto Alegre, RS, Brazil
}

\begin{abstract}
Nucleotide sequencing and phylogenetic analysis of Brazilian bovine viral diarrhea virus (BVDV) field isolates identified four viruses belonging to the genotype 2. Comparison of $5^{\prime}$ UTR sequences from these isolates to those of North American BVDV type 2 revealed genomic variations that correlated with the geographic origins of the isolates. Two of the Brazilian type 2 viruses were isolated from clinical cases of gastroenteric/respiratory disease and two were isolated from healthy bovine fetuses. The clinical cases affected young animals (8- and 18-months-old) and were characterized by diarrhea, respiratory signs, extensive oral and digestive tract erosions, conjunctival and vulvar congestion, occasional digestive bleeding and vulvar and heart petechial hemorrhage. Antigenic analysis of these isolates with a panel of 10 monoclonal antibodies revealed marked antigenic differences in the major envelope glycoprotein, gp53/E2, compared to standard laboratory and vaccine BVDV strains. In addition, virus-specific antisera raised to Brazilian BVDV type 2 viruses displayed very low serological cross-reactivity with standard BVDV type 1 strains. Differences up to 64-fold in cross-neutralization titers were observed between BVDV type 1 and Brazilian BVDV type 2 isolates. The identification of BVDV type 2 among Brazilian cattle may have important implications for epidemiological studies, diagnostic and immunization strategies. Furthermore, the low neutralizing activity of BVDV type 1 antisera against the recently identified
\end{abstract}

\footnotetext{
*Corresponding author. Tel.: +55-55-220-8055; fax: +55-55-220-8742 E-mail address: flores@ccr.ufsm.br (E.F. Flores).
} 
Brazilian BVDV type 2 isolates raises the question about the degree of protection conferred by BVDV vaccines, most of them based on a single type 1 strain. (C) 2000 Elsevier Science B.V. All rights reserved.

Keywords: Bovine viral diarrhea virus (BVDV); Genotypes; Antigenic diversity

\section{Introduction}

In the recent years, highly virulent bovine viral diarrhea virus (BVDV) strains have been associated with severe outbreaks of acute BVD, with deaths in all age groups in North America (Corapi et al., 1989; Alves et al., 1996; Carman et al., 1998). In addition, severe thrombocytopenia and hemorrhagic disease have been described in some herd epidemics (Corapi et al., 1989; Rebhun et al., 1989; Carman et al., 1998). Preliminary studies demonstrated that the isolates associated with these outbreaks were genetically and antigenically distinct from the classical BVDV strains. Phylogenetic analysis of a 268 nucleotide sequence within the $5^{\prime}$ untranslated region (UTR) of the viral RNA genome allowed the segregation of BVDV into two genotypes: BVDV type 1 and BVDV type 2 . The viruses isolated from the acute BVD/hemorrhagic disease outbreaks were classified as BVDV type 2, whereas the classical BVDV strains were classified either as BVDV type 1a or 1b (Pellerin et al., 1994; Ridpath et al., 1994). Retrospective studies have demonstrated the presence of BVD type 2 viruses among the North American cattle population for at least 20 years (Ridpath, unpublished). Nevertheless, BVDV type 2 have been mainly identified in the US and Canada, with a few reports of their presence in Europe (Wolfmeyer et al., 1997).

The objective of this article is to report the main clinical, pathological and antigenic features associated with BVDV type 2 isolates recently identified in Brazil. Phylogenetic analysis of 19 Brazilian BVDV isolates identified four viruses as belonging to genotype 2 . These viruses were isolated from clinical cases of gastroenteric/respiratory disease and from healthy fetuses, and were shown to be antigenically distinct from the standard BVDV strains.

\section{Material and methods}

\subsection{Clinical sampling, virus isolation and identification}

The standard BVDV strains (Singer, NADL, Oregon/C24v and BVDV-890) and the BVDV-specific monoclonal antibodies (MAbs) were kindly provided by Dr. Ruben Donis (Department of Veterinary and Biomedical Sciences, University of Nebraska at Lincoln, Lincoln, NE). The origin of 19 Brazilian BVDV isolates submitted to nucleotide sequencing and phylogenetic analysis, including those identified as BVDV type 2, has been reported previously (Gil, 1998). Virus isolation was performed through inoculation of clinical specimens onto pestivirus-free Madin-Darby bovine kidney cells (MDBK, American Type Culture Collection, Rockville, MD) followed by detection of viral 
antigens by indirect immunofluorescence (IFA). MDBK cells were routinely maintained in Eagle's minimal essential medium (MEM), contained penicillin (35 mg/l), streptomycin $(200 \mathrm{mg} / \mathrm{l})$, supplemented with $5 \%$ horse serum. IFA was performed in acetonefixed cells, using a pool of anti-BVDV Singer MAbs (Corapi et al., 1990) as the primary antibody and an FITC-conjugated anti-mouse IgG (Sigma-Aldrich, USA) as the secondary antibody. Samples positive for BVDV antigens were identified and the respective viruses were further amplified in MDBK cells. For histological examination, tissue samples collected at necropsy were fixed in $10 \%$ neutral-buffered formalin, embedded in paraffin, sectioned at $5 \mu \mathrm{m}$ and stained with hematoxylin-eosin using routine methods.

\subsection{Viral RNA amplification, sequencing and phylogenetic analysis}

Genotyping of Brazilian BVDV isolates was based on phylogenetic analysis of a highly conserved 268-nucleotide sequence located within the $5^{\prime}$ UTR of the viral RNA genome (Ridpath et al., 1994). PCR amplification of sequences from the $5^{\prime}$ UTR were performed as described by Ridpath and Bolin (1998). Both strands of each PCR product were sequenced in duplicate as described previously (Ridpath et al., 1994). Comparison and analysis of derived sequences were performed using the Align Plus (Scientific and Educational Software, State Line, PA), GeneWorks (Intelligenetics, Montain View, CA) and Dnasis (Hitachi Software, San Bruno, CA) software packages.

\subsection{Antigenic characterization}

The isolates were characterized antigenically with a panel of MAbs and by crossneutralization, using virus-specific antisera raised in lambs. Ten MAbs raised to the prototype BVDV Singer strain (Corapi et al., 1990) were used to characterize the Brazilian BVDV type 2 isolates. The ability of each individual MAb to recognize and bind to viral antigens was assayed by IFA. Mock-infected cells, cells infected with the prototype Singer strain and stained with each individual MAb and cells infected with each isolate and stained with a pool of MAbs were used as controls. For crossneutralization studies, virus-specific antiserum for each of the following BVD viruses was raised in lambs: reference BVDV-1 strains Singer, NADL and Oregon/C24v; BVDV-2 890; Brazilian isolates VS-63, VS-123.4, VS-260 and LV-96. Each of eight BVDVseronegative, 6-8-months-old lambs was inoculated intranasally and intramuscularly with tissue culture supernatant of infected MDBK cells containing approximately $10^{7}$ TCID $_{50}$ (median tissue culture infectious dose) of each virus. The animals were kept isolated from each other until the collection of serum. Sera were obtained 30 days post-inoculation (PI) and heat inactivated $\left(56^{\circ} \mathrm{C}\right.$ for $\left.30 \mathrm{~min}\right)$ prior to virus neutralization (VN) assays. Individual serum samples were initially titrated against their homologous viruses and subsequently titrated against each heterologous virus in a standard VN assay. Readings were performed after $96 \mathrm{~h}$ of incubation. Virus growth or neutralization was monitored by microscopic examination of cytopathic effect (CPE) for the cytopathic (CP) strains (Singer, NADL and Oregon/C24v) or by staining the cells by IFA for the non-cytopathic (NCP) viruses. Whenever a serum sample was titrated with different viruses, the VN tests 
were performed at the same time, in the same plate, using the same preparation of MDBK cells. The cross-neutralization tests yielded 64 values, corresponding to the VN titer of each virus-serum combination. These values are expressed as the reciprocal of the highest dilution of serum capable to prevent viral replication.

\section{Results}

\subsection{The Brazilian BVDV type 2 isolates}

The origin, nucleotide sequencing and phylogenetic analysis of 19 Brazilian BVDV isolates have been reported previously (Gil, 1998) and will be published elsewhere (Gil et al., in preparation). A summarized phylogenetic tree, including the four Brazilian BVDV type 2 isolates plus the North American reference BVDV-1a and $1 \mathrm{~b}$ and BVDV-2 strains is presented in Fig. 1. The epidemiological and clinical data concerning to the isolates identified as BVDV-2 are presented in Table 1. The four viruses were of the NCP biotype. Two of these viruses were isolated from healthy fetuses collected in a slaughterhouse, as part of a study aimed at determining the frequency of fetal infection by BVDV in southern Brazil (Botton et al., 1998). The other two viruses were isolated from specimens obtained from clinical cases.

\subsection{Clinical and pathological findings}

The main clinical and pathological findings associated with the clinical cases from which two BVDV type 2 viruses were isolated are described below. The animal case VS260 presented progressive anorexia, ruminal atony, brownish to dark changing to mucous bloody diarrhea, tenesmo, dehydration, conjunctival congestion, laborious breath, seropurulent nasal discharge and death. Clinical course was approximately 7-10 days. Gross lesions included widespread mucosal congestion, deep and extensive ulcerations in the tongue, palate and esophagus; congestion in the ruminal and omasal mucosa; multiple

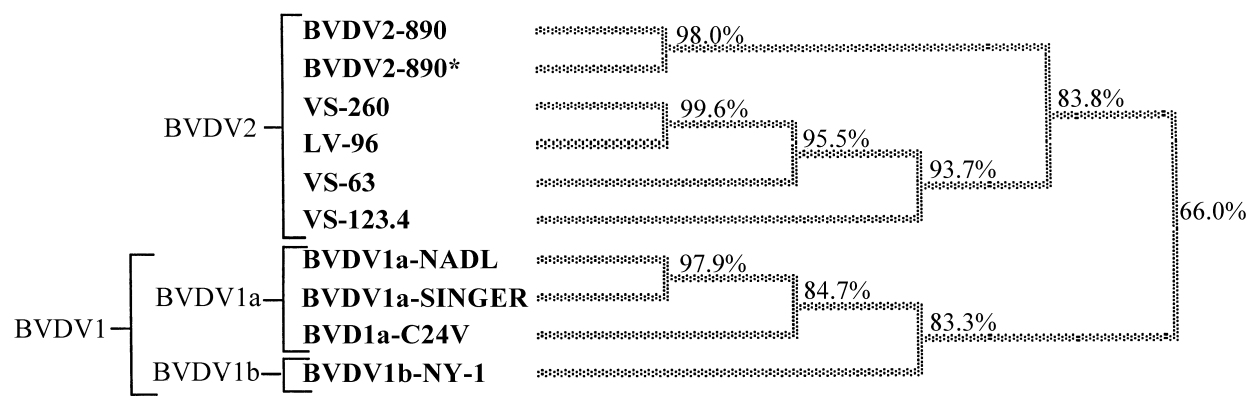

Fig. 1. Dendrogram analysis of the partial 5' UTR sequences of Brazilian BVDV type-2 (BVDV-2) isolates and North American reference BVDV-1a, 1b and BVDV-2 strains. BVDV-2 890 and 890* are the same viruses, grown in different laboratories. A high sequence similarity was observed among the Brazilian BVDV-2 isolates. 
Table 1

Origin of Brazilian BVDV type 2 isolates

\begin{tabular}{llllr}
\hline Identification & Biotype & Origin/clinical & Specimen & Year \\
\hline VS-63 $^{\text {a }}$ & NCP & Healthy fetus & Serum & 1996 \\
VS-123.4 $^{\text {a }}$ & NCP & Healthy fetus & Serum & 1996 \\
VS-260 $^{\text {a }}$ & NCP & Gastroenteric disease, 8-months-old heifer & Spleen & 1997 \\
LV-96 $^{\text {b }}$ & NCP & Chronic gastroenteric disease, 18-months-old heifer & Buffy coat & 1996 \\
\hline
\end{tabular}

${ }^{a}$ Viruses isolated and identified at the Virology Laboratory of the Department of Preventive Veterinary Medicine, Federal University of Santa Maria (UFSM), Santa Maria, RS, Brazil.

${ }^{\mathrm{b}}$ Virus isolated and identified at the Virology Laboratory of the Veterinary College, Federal University of Rio Grande do Sul (UFRGS), Porto Alegre, RS, Brazil.

white-yellowish spots diffusely distributed on the omasal mucosa. Disseminated areas of congestion and ulcerations covered with fibrin were observed in the small intestine, and petechial hemorrhages were seen in the epicardium and myocardium. Microscopic examination revealed deep ulcerations throughout the mucosa of the digestive tract; polymorphonuclear cell infiltrates in the mucosa of the tongue and esophagus; mono and polymorphonuclear infiltrates in the ruminal mucosa and submucosa; polymorphonuclear and lymphocytic infiltrates in the mucosa of small intestine.

The animal case LV-96 came from a herd which had previously experienced cases clinically compatible with BVD, including a "mucosal disease"-like disease in another animal. The animal case LV-96 displayed retarded growth, apathy and anorexia, recurrent periods of immunosuppressive-like disease in which diarrhea, interdigital dermatitis, conjunctivitis, arthritis and chronic pneumonia were prominent. Signs were progressive and the animal was euthanized after a clinical course of approximately 7 months. Gross examination revealed digestive tract erosions and ulcerations, often covered with necrotic plaques, including the hard palate, dental pad, tongue and esophagus; and antero-ventral pneumonia. Microscopic examination revealed necrotic foci in the rumen, and in the transition between omasum and reticulum. Digestive tract mucosal necrosis and ulcerations, fibrinoid necrosis in associated blood vessels were also observed. Serum samples collected at the onset of clinical signs and at the time of euthanasia showed an increase in VN antibody titer (against BVDV Singer strain) from negative to 400.

\subsection{Antigenic characterization}

\subsubsection{Reactivity with MAbs}

The virus isolates were biologically cloned and cells infected with the pure population of each virus were submitted to IFA, using 10 MAbs to the major envelope glycoprotein (gp53/E2) of the prototype BVDV Singer strain (Corapi et al., 1990). The profile of reactivity of these MAbs with each Brazilian isolate plus standard US BVDV-1 and BVDV-2 strains is presented in Table 2. Analysis of reactivity of these MAbs revealed marked antigenic differences in the envelope glycoprotein gp53/E2 compared to the standard BVDV strains. The isolate VS-63 was recognized by only two MAbs, whereas isolates VS-260, LV-96 and VS-123.4 reacted with three and five MAbs, respectively. In 
Table 2

Reactivity of a panel of MAbs to the prototype BVDV Singer strain with standard BVDV strains and Brazilian type 2 isolates $^{\mathrm{a}}$

\begin{tabular}{lllllllllll}
\hline Virus & \multicolumn{1}{l}{ MAbs to gp53/E2 } & \multicolumn{1}{l}{} & & & & \\
\cline { 2 - 10 } & 1 & 2 & 3 & 4 & 5 & 6 & 7 & 8 & 9 & 10 \\
\hline Singer & + & + & + & + & + & + & + & + & + & + \\
NADL & + & + & + & + & - & + & + & + & + & + \\
Oregon/C24v & + & - & + & - & - & + & + & + & + & - \\
890 & + & - & - & - & - & - & - & + & - & - \\
VS-63 & - & + & - & - & - & - & - & + & - & - \\
VS-123.4 & + & + & - & + & - & + & - & + & - & - \\
VS-260 & + & - & - & - & + & - & - & + & - & - \\
LV-96 & - & + & - & - & + & - & - & + & - & - \\
\hline
\end{tabular}

${ }^{\text {a }}$ As determined by IFA, using each MAb as primary antibody and an FITC-conjugate anti-mouse IgG as secondary antibody.

contrast, the standard BVDV strains NADL and Oregon/C24v were recognized by most of the MAbs. The pattern of MAb binding to BVDV-890 also differed from that observed for the standard BVDV-1 strains, being similar to that observed for the Brazilian BVDV-2 viruses (Table 2).

\subsubsection{Cross-neutralization}

Lambs inoculated with each of the Brazilian isolates and standard BVDV strains developed moderate to high VN titers against the homologous viruses (Table 3). Many of the antisera showed variable and often lower neutralizing activity when tested against heterologous viruses, with reductions up to 64-fold in VN titers being observed for some pairs of viruses. These results corroborate the results from the MAb analysis which revealed a considerable antigenic variation among these viruses. In general, the standard BVDV strains Singer, NADL and Oregon/C24v displayed a moderate to high serological

Table 3

Virus-neutralizing (VN) titers between pairs of homologous and heterologous BVDV isolates ${ }^{\mathrm{a}}$

\begin{tabular}{lrrrrrrrr}
\hline Virus & \multicolumn{7}{l}{ Antiserum to } \\
\cline { 2 - 9 } & Singer & NADL & Oregon & 890 & VS-123.4 & VS-63 & LV-96 & VS-260 \\
\hline Singer & 1280 & 640 & 160 & 80 & 160 & 40 & 20 & 20 \\
NADL & 320 & 640 & 80 & 40 & 80 & 20 & 20 & 20 \\
Oregon & 160 & 160 & 320 & $<10$ & 160 & 20 & 40 & 40 \\
890 & 40 & $<10$ & $<10$ & 640 & 320 & 320 & 160 & 320 \\
VS-123.4 & 80 & 20 & 20 & 160 & 1280 & 320 & 160 & 320 \\
VS-63 & 40 & 20 & $<10$ & 640 & 640 & 1280 & 160 & 160 \\
LV-96 & 80 & 10 & 20 & 320 & 320 & 1280 & 1280 & 640 \\
VS-260 & 80 & $<10$ & $<10$ & 320 & 320 & 640 & 640 & 1280 \\
\hline
\end{tabular}

${ }^{a} \mathrm{VN}$ titers are expressed as the reciprocal of the highest dilution capable of neutralizing the respective virus. Virus growth or neutralization was ascertained by monitoring the cytopathic effect (Singer, NADL, Oregon/ C24v) or by IFA (VS-63, 123.4, 260 and 890, and LV-96). 
cross-reactivity within the group. A similar degree of cross-reactivity was observed between the Brazilian isolates, and between these isolates and the BVDV-2 890. Testing the standard strains (antisera/virus) against the Brazilian isolates (and against BVDV890), revealed a low serological cross-reactivity between the two groups of viruses. These results allowed the clear identification of two serologically distinct groups of BVD viruses: one including the standard BVDV-1 strains Singer, NADL and Oregon/C24v, and another comprising the Brazilian isolates and BVDV-890. Among the Brazilian BVDV-2s isolates, VS-123.4 displayed the highest serological reactivity with the standard strains, particularly with BVDV Singer.

\section{Discussion}

Originally identified in outbreaks of severe disease, BVDV type 2 viruses were initially thought to be new and invariably virulent viruses. Subsequent studies demonstrated that viruses belonging to genotype 2 circulate among North American cattle population for at least 20 years (Carman et al., 1998; Ridpath, unpublished). These viruses are now beginning to be identified also in Europe (Wolfmeyer et al., 1997) and South America (Gil, 1998; Canal et al., 1998; Odeon et al., 1998), indicating that they are likely to be identified in other countries as epidemiological investigation proceeds. Moreover, evidence is being gathered showing that only a minor fraction of all type 2 BVDV isolates are highly virulent (Ridpath et al., 1994; Donis, 1998). Nowadays, around $40 \%$ of all BVD viruses isolated in North America are type 2 (Ridpath and Bolin, 1998). These findings support the idea that genotype 2 should not be taken as synonymous of high pathogenicity and virulence (Ridpath et al., 1994; Donis, 1998).

The origin, evolutionary history and epidemiological factors behind the emergence of BVDV type 2 remain a matter of dispute and controversy. Sequencing data from South American isolates are now beginning to emerge and may help in understanding the evolution and epidemiology of these viruses (Gil, 1998; Canal et al., 1998; Odeon et al., 1998). Preliminary phylogenetic analysis based on highly conserved $5^{\prime}$ UTR sequences revealed differences between North and South American BVDV type 2 isolates (Fig. 1; Gil, 1998; Gil et al., in preparation). These findings suggest that North and South American BVDV 2 isolates may belong to two different subgenotypes. Phylogenetic analysis of a larger number of South American isolates is obviously needed to support this hypothesis.

The clinical cases described in the present paper were very characteristic of BVDVassociated disease. Whereas one animal developed a long-lasting and wasting illness (LV96), the other heifer (VS-260) developed an acute and fatal disease. In the first case, the recent herd history had reports of clinical events compatible with BVDV infection, yet without virological confirmation; i.e. an acute and fatal gastroenteric disease with clinical features resembling those of heifer LV-96 and abortions in which fever and petechial hemorrhage were observed. The heifer LV-96 went through a long clinical course in which recurrent periods of diarrhea and immunosuppressive-like signs were observed. Recurrent interdigital dermatitis was also reported in this case. These features resemble what has been described as chronic BVD (Baker, 1995). In the case VS-260, the clinico- 
pathological findings were highly suggestive of mucosal disease (MD). However the isolation of a NCP, without the CP counterpart, and the subsequent genotyping of this isolate suggested that this was indeed a case of acute BVD caused by a BVDV type 2 virus.

The genotypic segregation of BVDV into genotypes 1 and 2 seems to correlate fairly well with the antigenic differences observed between these groups of viruses. BVDV isolates identified as belonging to genotype 2 display a very low serological crossreactivity with BVDV type 1 (Pellerin et al., 1994; Wolfmeyer et al., 1997). Therefore, in addition to the marked antigenic differences historically observed among BVDV (and pestiviruses in general) (Bolin et al., 1991; Dubovi, 1992), the recent identification of BVDV type 2 allowed the clear identification of two antigenically distinct groups of BVD viruses (Pellerin et al., 1994; Wolfmeyer et al., 1997). These findings have obvious implications for diagnosis, control, vaccine development and immunization strategies. The data from our study demonstrated a low serologic cross-reactivity between the Brazilian type 2 and the standard BVDV type 1 strains (Table 3). The marginal capacity of antisera to standard BVDV 1 strains to neutralize the Brazilian BVD type 2 viruses raises the question about the degree of protection conferred by commercially available vaccines and may indicate the need for formulation of vaccines based on Brazilian isolates.

\section{Acknowledgements}

This work was supported by the MCT, CNPq, CAPES and FINEP grants (PRONEX in Veterinary Virology, 215/96). E. Flores (352386/96) and R. Weiblen (520161/97-1) had research scholarships from the Brazilian Council for Research (CNPq). We thank Dr. Ruben Donis (Department of Veterinary and Biomedical Sciences, University of Nebraska at Lincoln. Lincoln, NE) for providing the MAbs and the reference BVDV strains. The technical assistance of E.A.S. Oliveira in performing the SN tests of the case LV-96 is greatly appreciated.

\section{References}

Alves, D., Tremblay, R., Godkin, A., Anderson, N., Carman, S., McEwen, B., Hazlett, M., 1996. Update on bovine virus diarrhea in Ontario. Can. Vet. J. 37, 177.

Baker, J.C., 1995. The clinical manifestations of bovine viral diarrhea infections. Vet. Clin. N. Am. 11, $427-444$.

Bolin, S.R., Littledike, E.T., Ridpath, J.F., 1991. Serologic detection and practical consequences of antigenic diversity among bovine viral diarrhea virus in a vaccinated herd. Am. J. Vet. Res. 52, 1033-1047.

Botton, S.A., Gil, L.H.V.G., Silva, A.M., Flores, E.F., Weiblen, R., Pituco, E.M., Roehe, P.M., Moojen, V., Wendelstein, A.C., 1998. Caracterização preliminar de amostras do vírus da diarréia viral bovina (BVDV) isoladas no Brasil. Pesq. Vet. Bras. 18, 84-92.

Canal, C.W., Strasser, M., Hertig, C., Masuda, A., Peterhans, E., 1998. Detection of antibodies to bovine viral diarrhea virus (BVDV) and characterization of genomes of BVDV from Brazil. Vet. Microbiol. 63, 85-97.

Carman, S., Van Dreumel, T., Ridpath, J., Hazlett, M., Alves, D., Dubovi, E.J., Tremblay, R., Bolin, S.R., Godkin, A., Anderson, N., 1998. Severe acute bovine viral diarrhea (BVD) in Ontario, 1993-1995. J. Vet. Diagn. Invest. 10, 27-35. 
Corapi, W.V., French, T.W., Dubovi, E.J., 1989. Severe thrombocytopenia in young calves experimentally infected with noncytopathic bovine viral diarrhea virus. J. Virol. 62, 2823-2827.

Corapi, W.V., Donis, R.O., Dubovi, E.J., 1990. Characterization of a panel of monoclonal antibodies and their use in the study of the antigenic diversity of bovine viral diarrhea virus. Am. J. Vet. Res. 51, 1388-1394.

Donis, R., 1998. Molecular evolution of highly virulent pestivirus strains which cause acute severe BVD in cattle. In: Proceedings of the International Symposium on Bovine Herpesvirus Types 1 and 5 and Bovine Viral Diarrhea Virus. Santa Maria, RS, Brazil, pp. 21-31.

Dubovi, E.J., 1992. Genetic diversity and BVD virus. Comp. Immunol. Microbiol. Infect. Dis. 15, 155-165.

Gil, L.H.V.G., 1998. Sequenciamento, análise filogenética e caracterização de polipeptídeos não-estruturais de amostras do vírus da diarréia viral bovina (BVDV). MS Thesis. Santa Maria, RS, UFSM, 1998, 69 pp.

Odeon, A.C., Kaiser, G.G., Donis, R.O., Risatti, G., Leunda, M.R., 1998. Aislamiento y análisis molecular del vírus de la diarrea viral bovina genotipo II en Argentina. In: Proceedings of the XII Reunión Científico Técnica. As. Arg. Vet. Lab. Diagn. 12, 94.

Pellerin, C., van den Hurk, J., Lecomte, J., 1994. Identification of a new group of bovine viral diarrhea virus strains associated with severe outbreaks and high mortalities. Virology 203, 260-267.

Rebhun, W.C., French, T.W., Perdrizet, J.A., Dubovi, E.J., Dill, S.G., Karcher, L.F., 1989. Thrombocytopenia associated with acute bovine virus diarrhea infection in cattle. J. Vet. Intern. Med. 3, 42-46.

Ridpath, J.F., Bolin, S.R., 1998. Differentiation of types 1a, 1b and 2 bovine viral diarrhea virus (BVDV) by PCR. Mol. Cell Probes 12, 101-106.

Ridpath, J., Bolin, S., Dubovi, E., 1994. Segregation of bovine viral diarrhea virus into genotypes. Virology 205 , 66-74.

Wolfmeyer, A., Wolf, G., Beer, M., 1997. Genomic (5'UTR) and serological differences among German BVDV field isolates. Arch. Virol. 142, 2049-2057. 